\title{
Article
}

\section{Is undernutrition prognostic of infection complications in children undergoing surgery? A systematic review}

Hill, Rebecca, Paulus, S., Dey, Maria Paola, Hurley, Margaret Anne and Carter, Bernie

Available at http://clok.uclan.ac.uk/14228/

Hill, Rebecca, Paulus, S., Dey, Maria Paola, Hurley, Margaret Anne ORCID: 0000-0002-2502-432X and Carter, Bernie ORCID: 0000-0001-5226-9878 (2016) Is undernutrition prognostic of infection complications in children undergoing surgery? A systematic review. Journal of Hospital Infection, 93 (1). pp. 12-21. ISSN 01956701

It is advisable to refer to the publisher's version if you intend to cite from the work. http://dx.doi.org/10.1016/j.jhin.2015.12.020

For more information about UCLan's research in this area go to http://www.uclan.ac.uk/researchgroups/ and search for <name of research Group>.

For information about Research generally at UCLan please go to http://www.uclan.ac.uk/research/

All outputs in CLoK are protected by Intellectual Property Rights law, including Copyright law. Copyright, IPR and Moral Rights for the works on this site are retained by the individual authors and/or other copyright owners. Terms and conditions for use of this material are defined in the policies page.

\section{CLoK}

Central Lancashire online Knowledge www.clok.uclan.ac.uk

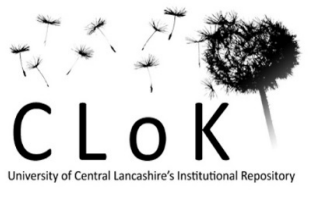


Review

\title{
Is undernutrition prognostic of infection complications in children undergoing surgery? A systematic review
}

\author{
R. Hill ${ }^{a, *}$, S. Paulus ${ }^{b, c}$, P. Dey ${ }^{e}$, M.A. Hurley ${ }^{f}$, B. Carter ${ }^{d, g}$ \\ a Department of Paediatric Cardiology and Cardiac Surgery, Alder Hey Children's NHS Foundation Trust, Liverpool, UK \\ ${ }^{\mathrm{b}}$ Department of Infectious Diseases, Alder Hey Children's NHS Foundation Trust, Liverpool, UK \\ c Institute of Infection and Global Health, University of Liverpool, Liverpool, UK \\ 'Children's Nursing Research Unit, Alder Hey Children's NHS Foundation Trust, Liverpool, UK \\ e College of Clinical and Biomedical Science, University of Central Lancashire, Preston, UK \\ ${ }^{f}$ College of Health and Wellbeing, University of Central Lancashire, Preston, UK \\ ${ }^{g}$ Faculty of Health and Social Care, Edge Hill University, Ormskirk, UK
}

\section{A R T I C L E I N F O}

\section{Article history:}

Received 2 September 2015

Accepted 30 December 2015

Available online $\mathrm{xxx}$

Keywords:

Healthcare-associated infection Undernutrition

Nutritional assessment

Paediatric surgery

Postoperative infection

\section{$S \cup M M A R$}

Background: Healthcare-associated infections are costly and are increasingly viewed as an indicator of the quality of care. Although strategies to reduce infections have become widespread, few studies have formally investigated the role of undernutrition on the development of infection-related complications in children after surgery.

Aim: To perform a systematic review of the literature to determine if undernutrition is prognostic of postoperative infection complications in children.

Methods: Electronic bibliographic and research databases were searched from 1950 to 2014. Inclusion criteria were studies in children (age $<18$ years) evaluating pre-operative nutritional status and reporting postoperative infection complications. Quality assessment was performed independently by two reviewers, with disagreements resolved by a third reviewer. The quality of the evidence was judged to be low in the majority of studies.

Findings: Ten cohort and two case-control studies met the inclusion criteria. Five studies reported an outcome combining infection-related complications, with the remainder reporting individual infection complications. Six studies reported surgical site infection (SSI) alone or in combination with other infection complications. Direct comparison between studies was difficult due to clinical and diagnostic heterogeneity. Unadjusted analyses (for patient or clinical variables) were suggestive of a relationship between undernutrition and infection complications. In studies controlling for other variables, the analyses did not remain significant for SSI.

Conclusion: There was low-quality evidence that undernutrition may be predictive of postoperative infection complications in children, with the exception of SSI. However, inconsistencies in nutritional and outcome assessments made it difficult to draw conclusions. Larger, high-quality studies are warranted to further investigate a potential prognostic relationship.

(C) 2016 Published by Elsevier Ltd on behalf of the Healthcare Infection Society.

\footnotetext{
* Corresponding author. Address: Department of Paediatric Cardiology and Cardiac Surgery, Alder Hey Children's NHS Foundation Trust, Eaton Road, Liverpool L12 2AP, UK. Tel.: +44 (0)151 2824515.

E-mail address: rebecca.hill@alderhey.nhs.uk (R. Hill).
} 


\section{Introduction}

Healthcare-associated infections (HCAls) cost the National Health Service (NHS) in excess of $£ 700$ million per year. ${ }^{1}$ In addition, HCAl rates are increasingly being viewed as an indicator of the quality of health care. ${ }^{2}$ Efforts to reduce the incidence of HCAls have become widespread, and include the introduction of evidence-based clinical guidelines for reducing surgical site infection (SSI) in the UK and USA. ${ }^{3,4}$ Few studies in children have investigated nutritional status, particularly undernutrition, as a risk factor for postoperative infectionrelated complications. Undernutrition can be defined as an imbalance between nutrient requirement and intake, resulting in cumulative deficits of energy, protein or micronutrients, that may have a negative effect on growth, development and other outcomes. ${ }^{5}$ There is evidence that nutritional status deteriorates in children following hospital admission, ${ }^{6,7}$ often when associated with chronic or critical illness. ${ }^{8,9}$

Poor nutritional status (measured by lower weight-for-age $z$ scores) has been associated with increased duration of mechanical ventilatory support, increased length of stay and increased one-year mortality in neonates undergoing surgery within an intensive care setting. ${ }^{10} \mathrm{~A}$ recent evidence-based review of the literature found weak evidence of preoperative nutritional assessment being predictive of adverse clinical outcomes in paediatric surgical patients. ${ }^{11}$ However, this review only identified six studies in total, five of which were undertaken in a paediatric cardiac surgical population, limiting the validity of these findings to other surgical populations. Moreover, only two of the included studies reported infection-related outcomes. ${ }^{12,13}$

These observations indicate that the relationship between undernutrition and postoperative infection complications in children has not been fully delineated, justifying the need for a systematic review of the existing research literature. The subject area is important because nutritional status is a potentially modifiable risk factor. Reduction in infectionrelated complications after surgery can reduce the physical and psychosocial impact on both the child and his/her family, reduce the financial burden associated with medical or surgical management, and avoid prolonged hospital stay or readmission. The costs associated with these adverse events have not been evaluated to date in paediatric surgical populations.

\section{Methods}

All studies assessing the pre-operative nutritional status of children aged $<18$ years undergoing surgery and reporting infection-related postoperative complications were eligible for inclusion. Studies that also included participants aged $>18$ years were excluded if outcome data for younger ages were not available separately. Studies were identified by searching the Cochrane Central Register of Controlled Trials (CENTRAL), OvidSP MEDLINE (1950-2014), OvidSP EMBASE (1980-2014) and NHS Evidence CINAHL (1982-2014). Index terms were exploded. A search strategy sensitive to the identification of prognostic studies was adopted. ${ }^{14,15}$ Studies were also identified by forward and backward citation searching of all identified papers and relevant review articles. OpenGrey and ETHos were searched in an attempt to identify relevant grey literature. Only studies published in the English language were included.

The database search strategy resulted in 1067 citations with 28 duplicate titles. No further studies were identified by the CENTRAL database or grey literature searching. Following an independent review of the titles, 970 were discarded. A further 28 citations were identified by forward and backward citation searching of the remaining 69 database citations, and 14 of these were discarded following abstract screening. In total, 83 full-text articles were screened, with 30 discarded immediately following confirmation of the age of the participants. In total, 53 articles progressed to full eligibility screening. Two articles referring to the same study were identified. ${ }^{16,17}$ Data from both papers were combined for data extraction purposes. Finally, 10 cohort studies and two case-control studies were included in this review (Figure 1).

Data extraction was performed using forms specific to this review and based on the Cochrane Collaboration template. ${ }^{18}$ When further clarity on content was required, the primary authors were contacted. Where more than one published paper reported results from the same study participants, all papers were used to gain information relevant to this review.

The following data were extracted: study design and characteristics; country of origin; type and length of surgery; baseline participant data and eligibility criteria; nutritional assessment method with stratification of nutritional status; infection-related outcomes including definition, incidence and size of effect; duration of follow-up; assessment of confounders; and authors' conclusion.

For dichotomous infection outcomes, the appropriate relative risk or odds ratios were extracted or calculated, accompanied by $95 \%$ confidence intervals. Where more than one analysis was presented in the published article, the most adjusted analysis was extracted. Studies demonstrated significant clinical and methodological heterogeneity in terms of participants and outcome reporting; therefore, meta-analysis was not appropriate and a narrative synthesis was used to explore the relationship between classification of nutritional status and incidence of infection-related complications.

\section{Quality assessment of included studies}

The methodological quality of studies that met the inclusion criteria was assessed independently. The Newcastle-Ottawa Scale (NOS) ${ }^{19}$ has a version for both cohort and case-control studies, and so was used to assess study quality in three domains: participant selection (representativeness), comparability (due to design or analysis) and outcomes (assessment and follow-up). All decisions regarding study quality were based upon the information presented in the published paper. Studies scoring the maximum score of 9 were considered to provide high-quality evidence, studies scoring 7 or 8 were considered to provide moderate-quality evidence, studies scoring 5 or 6 were considered to provide low-quality evidence, and studies scoring $<4$ were considered to provide very-low-quality evidence.

Participants needed to reflect the 'average' paediatric surgical population, and so were judged accordingly. Specialist, homogenous surgical populations were downgraded for the purposes of this review, ${ }^{20}$ and studies recruiting from voluntary surgical databases were judged to be at unclear risk of bias. ${ }^{21}$ 


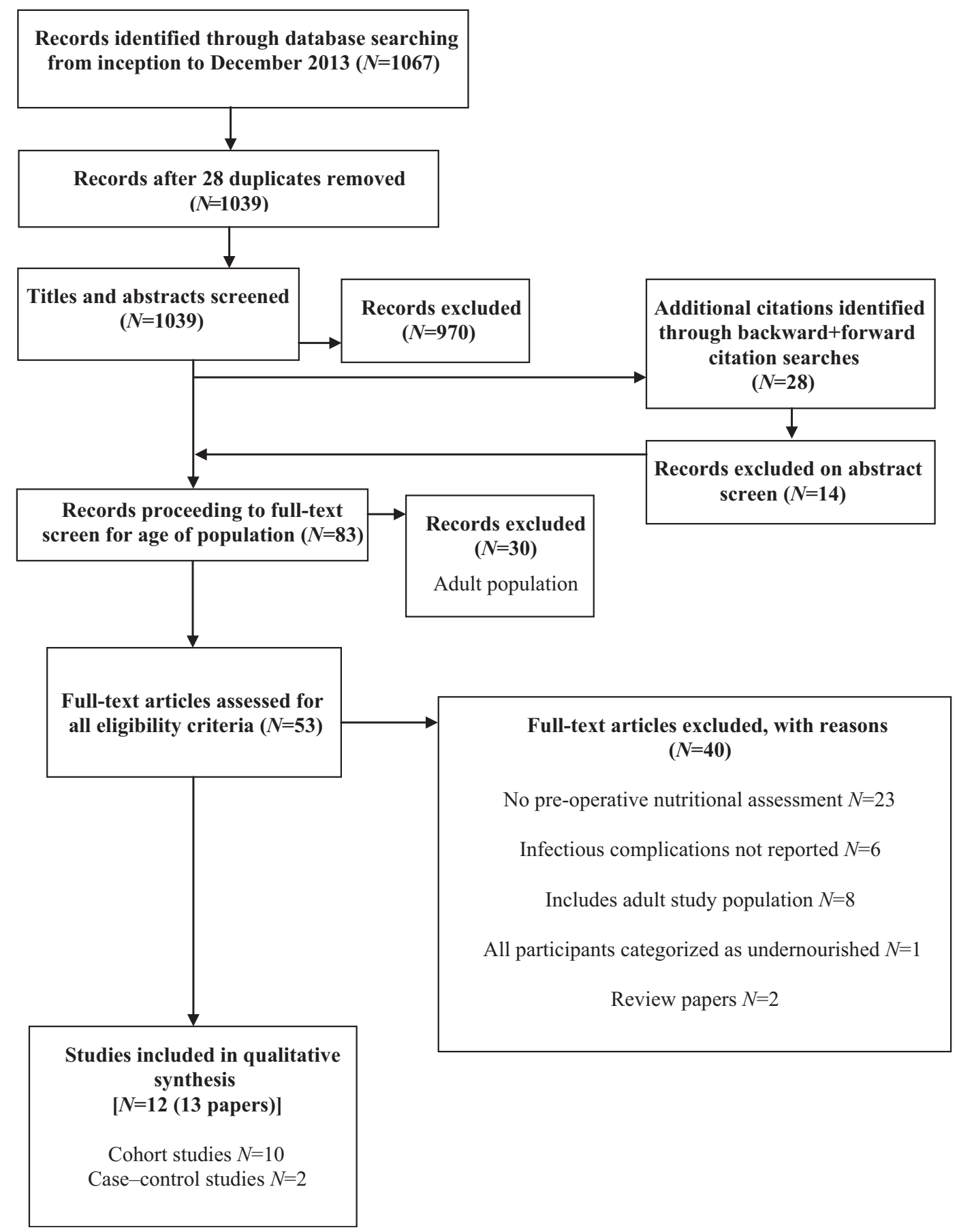

Figure 1. Flow diagram of results from search strategy and study selection.

As body mass index (BMI) is not a valid indicator of undernutrition in children without being adjusted for age and sex, ${ }^{22}$ studies using $\mathrm{BMI}$ as their sole ascertainment of undernutrition were downgraded accordingly. ${ }^{28}$ Where cut-offs for categories of nutritional status were defined inadequately to make a judgement, studies were judged to be at unclear risk of bias. ${ }^{24}$ Studies that excluded participants based on age, co-morbidity, death and/or incomplete follow-up data were downgraded. Lack of transparency regarding the number of participants excluded from the studies was considered a potential source of bias, especially when excluded populations accounted for $20 \%$ of the surgical cohort. ${ }^{23,24}$ Where participant numbers were low for the given study period, studies were downgraded to unclear risk of bias. ${ }^{13,25,26}$ Unclear or non-validated infection definitions, ${ }^{25}$ or unclear or less than accepted durations of follow-up made it difficult to assess exposure and/or case selection; these studies were downgraded accordingly. ${ }^{13,16,17,20,21,24,26}$

Any study that adjusted for age and/or case complexity met the criteria for comparability. ${ }^{20,21,23,24}$ Studies that did not provide details about adjustment, studies that reported 'no difference between groups', and studies that undertook 


\section{R. Hill et al. I Journal of Hospital Infection xxx (2016) 1-10}

unadjusted analysis alone were not considered to have met the criteria for comparability. ${ }^{13,16,17,24,27}$

The results of quality assessment are presented in Table I. Overall, two studies were rated as moderate quality and eight studies were rated as low quality. The remaining cohort studies were rated as very low quality.

\section{Results}

\section{Search results}

Twelve studies (13 papers) with a sum total of 92,386 participants fulfilled the inclusion criteria for this review. The effect estimates of the results for individual studies regarding the relationship between nutritional status and infection outcome are shown in Table II. All participants had some form of nutritional assessment undertaken prior to their surgery, classified within this table as the prognostic indicator.

Two studies included participants aged $\geq 18$ years. ${ }^{25,28}$ As both presented individual patient characteristics with related outcome data, these participants were excluded from univariate statistical analysis. Three papers excluded neonates: Rojratsirikul et al. excluded infants aged less than two months, ${ }^{27}$ whilst Secker and Jeejeebhoy and Stey et al. excluded neonates aged $<31$ days and $<28$ days, respectively. ${ }^{12,21}$ The remaining 10 studies were performed in children with a minimum age of three days and overall median age of 10.6 months. ${ }^{23}$

Four studies were undertaken in cardiac surgical populations, ${ }^{13,20,21,29}$ and four studies were undertaken in general surgical populations, mainly gastrointestinal/abdominal surgery. ${ }^{16,17,26,27}$ Two studies were performed in spinal surgical populations, ${ }^{25,29}$ and one study comprised of cardiac, neurosurgical and general surgical participants. ${ }^{24}$ Stey et al. reported on all children undergoing any type of surgery with data entered on to the American College of Surgeons National Surgical Quality Improvement Program Pediatric Report Form. ${ }^{21}$

\section{Methods of nutritional assessment}

A variety of methods were used to assess nutritional status, and 13,902 participants were classified as undernourished, giving a combined incidence of $15 \%$. This incidence was $>50 \%$ in four of the included studies, ${ }^{12,13,23,26}$ and the lowest rate was found in the largest cohort study which reported an incidence of $14.5 \%{ }^{21}$

A formula using height and/or weight parameters was most commonly used to assess nutritional status. Five studies relied on weight-for-age $z$-scores s.,21,29 $^{2}$ or BMI z-score calculations. ${ }^{23,28}$ Prospective studies were more likely to use Waterlow's criteria based on expected values of height/weight for age. ${ }^{13,16,17,26}$ Two studies used one of the above measures with the addition of triceps skin fold; the latter was used to estimate subcutaneous fat. ${ }^{13,26}$

Two studies included some element of laboratory testing. ${ }^{13,26}$ One study used laboratory measures (serum albumin and haematocrit) alone to classify nutritional status. ${ }^{25}$ Two studies compared a nutrition history questionnaire, the Subjective Global Assessment, against anthropometric assessments to assess the efficacy of the tool in identifying children at risk of postoperative complications. ${ }^{12,27}$ The focus of these studies was to identify and compare undernourished children with their well-nourished counterparts; outcome data were extracted for both groups.

\section{Relationship between undernutrition and infection}

Six studies reported outcomes for SSI (Table II). 16,21,24,25,28,29 Definitions used for the identification of this outcome were consistent across the three studies ${ }^{21,24,28}$ that used the criteria of the Centers for Disease Control and Prevention. ${ }^{4}$ Bhattacharyya and Kosloske ${ }^{16}$ used an ASEPSIS score $>21$, whilst Nateghian et al. ${ }^{29}$ used the National Nosocomial Infections Surveillance criteria, both of which are recognized criteria. ${ }^{30,31}$ The remaining study within a spinal surgical population used an individualized definition, described as wound breakdown with purulence, exposed instrumentation or positive wound culture. ${ }^{25}$

Two of the six studies performed adjusted analyses controlling for important clinical factors (age, case mix and comorbidity), and the results did not demonstrate an association between undernutrition and SSI. ${ }^{21,24}$ The studies were well powered, but both had significant participant exclusions. On unadjusted results, only one paper reported a relative risk of $1,{ }^{16}$ whilst the remaining studies presented relative risks $>1 .^{25,28,29}$ However, only one study demonstrated confidence intervals suggestive of statistical significance. ${ }^{25}$

Five studies reported an outcome for combined infectionrelated complications; ${ }^{12,13,20,23,27}$ two of these reported significant relative risks, indicating an association between undernutrition and infection. ${ }^{12,20}$ This association persisted in the study that undertook adjusted analysis. ${ }^{20}$ Two studies reported no episodes of infection in the normally nourished groups; ${ }^{13,27}$ in one of these studies, there was a significantly increased risk of infection in undernourished patients. ${ }^{13}$ The remaining study did not find an association between nutrition status and the risk of three infections (pneumonia, mediastinitis and septicaemia), but the very short duration of follow-up was unlikely to have allowed ascertainment of all cases of infection. ${ }^{23}$

Outcome data for pneumonia were available from four studies, all of which reported unadjusted risk estimates. ${ }^{17,21,23,26}$ However, the direction of effect was not consistent across studies, with only one study achieving statistical significance. ${ }^{21}$ Two studies did not provide sufficient data to allow interpretation. ${ }^{17,26}$

Stey et al. presented unadjusted results of statistical significance, demonstrating an association between undernutrition and postoperative urinary tract infection; however, this was not included in the adjusted analysis. ${ }^{21}$ Bhattacharrya and Kosloske presented data for septicaemia, which also demonstrated an association with undernutrition on univariate analysis. ${ }^{17}$ However, the confidence intervals were extremely wide.

\section{Discussion}

This systematic review shows that there is insufficient evidence to assess any association between undernutrition and the risks of SSI, pneumonia or septicaemia. There is, however, tentative evidence of a relationship between undernutrition and the risk of developing any infection-related complication. There is also weak evidence to suggest an association between undernutrition and postoperative urinary tract infection. 
Table I

Summary of methodological quality of included studies: review authors' judgements

\begin{tabular}{|c|c|c|c|c|c|c|c|c|c|c|}
\hline \multirow{3}{*}{\multicolumn{2}{|c|}{ Cohort studies }} & \multicolumn{9}{|c|}{ Quality assessment criteria } \\
\hline & & \multicolumn{4}{|c|}{ Selection criteria } & \multirow[b]{2}{*}{$\begin{array}{l}\text { Comparability } \\
\text { of cohorts }\end{array}$} & \multicolumn{3}{|c|}{ Outcome criteria } & \multirow[b]{2}{*}{$\begin{array}{l}\text { Overall } \\
\text { quality of } \\
\text { the evidence }\end{array}$} \\
\hline & & $\begin{array}{l}\text { Representativeness } \\
\text { of the exposed } \\
\text { cohort }\end{array}$ & $\begin{array}{c}\text { Selection of } \\
\text { the non-exposed } \\
\text { cohort }\end{array}$ & $\begin{array}{l}\text { Ascertainment } \\
\text { of exposure }\end{array}$ & $\begin{array}{c}\text { Demonstration that } \\
\text { outcome not present } \\
\text { at start }\end{array}$ & & $\begin{array}{l}\text { Assessment } \\
\text { of outcome }\end{array}$ & $\begin{array}{l}\text { Duration of } \\
\text { follow-up } \\
\text { sufficient }\end{array}$ & $\begin{array}{l}\text { Adequacy of } \\
\text { follow-up }\end{array}$ & \\
\hline \multicolumn{2}{|l|}{ Al Bassam 1994} & $\mathrm{U}$ & * & * & * & $\mathrm{I}$ & * & $\mathrm{U}$ & $\mathrm{U}$ & Very low \\
\hline \multicolumn{2}{|c|}{ Anderson et al., 2011} & $\mathrm{U}$ & * & * & * & $* *$ & * & $\mathrm{U}$ & * & Moderate \\
\hline \multicolumn{2}{|c|}{ Bhattacharyya et al., 1990, 1993} & $\mathrm{U}$ & * & * & $\mathrm{U}$ & I & * & $U$ & $U$ & Very low \\
\hline \multicolumn{2}{|c|}{ Hatlen et al., 2010} & U & * & $u$ & * & U & * & * & * & Low \\
\hline \multicolumn{2}{|c|}{ Leite et al., 1995} & $U$ & * & * & * & I & * & $U$ & * & Low \\
\hline \multicolumn{2}{|c|}{ Porras-Hernandez et al., 2003} & $\mathrm{U}$ & * & $u$ & * & * & * & $\mathrm{U}$ & * & Low \\
\hline \multicolumn{2}{|c|}{ Rojratsirikul et al., 2004} & $\mathrm{U}$ & * & * & * & I & * & * & * & Low \\
\hline \multicolumn{2}{|c|}{ Secker and Jeejeebhoy, 2007} & $\mathrm{U}$ & * & * & * & $U$ & * & * & * & Low \\
\hline \multicolumn{2}{|c|}{ Stey et al., 2014} & $U$ & * & * & * & $* *$ & * & $\mathrm{U}$ & * & Moderate \\
\hline \multicolumn{2}{|c|}{ Vivanco-Munoz et al., 2010} & 1 & * & U & * & * & * & 1 & * & Low \\
\hline \multirow{2}{*}{$\begin{array}{l}\text { Case-control } \\
\text { studies }\end{array}$} & \multicolumn{4}{|c|}{ Selection criteria } & & \multicolumn{4}{|c|}{ Outcome criteria } & \\
\hline & $\begin{array}{l}\text { Case definition } \\
\text { adequate }\end{array}$ & $\begin{array}{l}\text { Representativeness } \\
\text { of the cases }\end{array}$ & $\begin{array}{l}\text { Selection of } \\
\text { the controls }\end{array}$ & $\begin{array}{l}\text { Definition } \\
\text { of controls }\end{array}$ & $\begin{array}{l}\text { Comparability of } \\
\text { cases and controls }\end{array}$ & $\begin{array}{l}\text { Ascertainment } \\
\text { of exposure }\end{array}$ & $\begin{array}{r}\text { Same me } \\
\text { of ascertai } \\
\text { of expos }\end{array}$ & $\begin{array}{l}\text { thod } \\
\text { inment } \\
\text { sure }\end{array}$ & $\begin{array}{l}\text { lon-response } \\
\text { rate }\end{array}$ & $\begin{array}{c}\text { Overall } \\
\text { quality of } \\
\text { the evidence }\end{array}$ \\
\hline $\begin{array}{l}\text { Farley } \\
\text { et al., } 2014\end{array}$ & $U$ & * & * & * & 1 & 1 & * & & * & Low \\
\hline $\begin{array}{l}\text { Nateghian } \\
\text { et al., } 2004\end{array}$ & 1 & * & * & * & U & * & * & & * & Low \\
\hline
\end{tabular}

*, criterion met; U, unclear; I, inadequate. 
Summary of findings, ordered by outcome and outcome effect

\begin{tabular}{|c|c|c|c|c|c|c|c|c|c|}
\hline $\begin{array}{l}\text { Study } \\
\text { (reference) and } \\
\text { location }\end{array}$ & Year & Study aims & Study design & $\begin{array}{l}\text { Study } \\
\text { quality }\end{array}$ & Participants & Prognostic indicator & $\begin{array}{c}\text { Outcomes relevant to } \\
\text { this review }\end{array}$ & $\begin{array}{l}\text { Results } \\
\text { RR or OR } \\
(95 \% \mathrm{Cl})\end{array}$ & \\
\hline $\begin{array}{l}\text { Anderson } \\
\text { et al. }{ }^{20} \\
\text { USA }\end{array}$ & 2011 & $\begin{array}{l}\text { To identify specific } \\
\text { anthropometric and } \\
\text { cardiovascular variables } \\
\text { predicting lower weight- } \\
\text { for-age } z \text {-scores and } \\
\text { poorer short-term } \\
\text { surgical outcomes at } \\
\text { operation (completion of } \\
\text { Fontan) }\end{array}$ & $\begin{array}{l}\text { Retrospective } \\
\text { case series } \\
\text { (cohort) }\end{array}$ & Moderate & $\begin{array}{l}55 \text { paediatric patients } \\
\text { undergoing cardiac } \\
\text { surgery (completion of } \\
\text { Fontan) } \\
\text { Median age } 47 \text { months } \\
\text { (range } 18-71 \text { months) }\end{array}$ & $\begin{array}{l}\text { Weight-for-age } z- \\
\text { score }<-2.0\end{array}$ & $\begin{array}{l}\text { Combined infection- } \\
\text { related } \\
\text { complications } \\
\text { (unclear criteria) }\end{array}$ & $\begin{array}{l}\text { RR } 3.6 \\
(1.17-11.05)\end{array}$ & ?ִ \\
\hline $\begin{array}{l}\text { Secker and } \\
\text { Jeejeebhoy }{ }^{12} \\
\text { Canada }\end{array}$ & 2007 & $\begin{array}{l}\text { To determine if } \\
\text { Subjective Global } \\
\text { Nutritional Assessment } \\
\text { can predict nutrition- } \\
\text { associated complications } \\
\text { and length of hospital } \\
\text { stay after surgery in } \\
\text { children }\end{array}$ & $\begin{array}{l}\text { Prospective } \\
\text { cohort study }\end{array}$ & Low & $\begin{array}{l}175 \text { children undergoing } \\
\text { non-emergency } \\
\text { abdominal or non- } \\
\text { cardiac thoracic surgery } \\
\text { Mean age } 8.1 \text { years, } \\
\text { standard deviation } 6.1 \\
\text { years }\end{array}$ & $\begin{array}{l}\text { Subjective Global } \\
\text { Nutritional } \\
\text { Assessment (Class B or } \\
\text { C); compared against } \\
\text { anthropometric } \\
\text { measurements }\end{array}$ & $\begin{array}{l}\text { Combined infection- } \\
\text { related } \\
\text { complications (CDC } \\
\text { criteria) }\end{array}$ & $\begin{array}{l}\text { RR } 1.53 \\
(1.02-2.32)\end{array}$ & 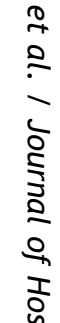 \\
\hline $\begin{array}{l}\text { Leite et al. }{ }^{13} \\
\quad \text { Brazil }\end{array}$ & 1995 & $\begin{array}{l}\text { To evaluate poor } \\
\text { nutritional status as a } \\
\text { risk factor for } \\
\text { postoperative } \\
\text { complications in children } \\
\text { with congenital heart } \\
\text { disease }\end{array}$ & $\begin{array}{l}\text { Prospective } \\
\text { cohort study }\end{array}$ & Low & $\begin{array}{l}50 \text { children undergoing } \\
\text { cardiac surgery divided } \\
\text { into high-risk and low- } \\
\text { risk operations } \\
\text { Median age (high risk) } 12 \\
\text { months (range } 3-134 \\
\text { months); median age } \\
\text { (low risk) } 42 \text { months } \\
\text { (range 3-140 months) }\end{array}$ & $\begin{array}{l}\text { Weight/height below } \\
10^{\text {th }} \text { percentile; arm } \\
\text { circumference below } \\
\text { fifth percentile; } \\
\text { albumin; transferrin; } \\
\text { pre-albumin }\end{array}$ & $\begin{array}{l}\text { Combined infection- } \\
\text { related } \\
\text { complications } \\
\text { (Buzby et al., } 1998 \\
\text { criteria) }\end{array}$ & $\begin{array}{l}\text { Infinity } \\
P \leq 0.001 \\
\text { (no infection in } \\
\text { normally } \\
\text { nourished group) }\end{array}$ & 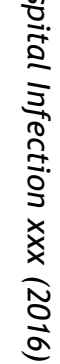 \\
\hline $\begin{array}{l}\text { Rojtatsirikul } \\
\text { et al. } \\
\text { Thailand }\end{array}$ & 2004 & $\begin{array}{l}\text { To evaluate the pre- } \\
\text { operative nutritional } \\
\text { status of paediatric } \\
\text { surgical patients and to } \\
\text { determine the validity of } \\
\text { Subjective Global } \\
\text { Assessment as a } \\
\text { screening tool }\end{array}$ & $\begin{array}{l}\text { Prospective } \\
\text { cohort study }\end{array}$ & Low & $\begin{array}{l}78 \text { children aged } 2 \\
\text { months-16 years } \\
\text { admitted consecutively } \\
\text { for mainly } \\
\text { gastrointestinal or } \\
\text { inguino-scrotal surgery } \\
\text { Median age } 4.5 \text { years }\end{array}$ & $\begin{array}{l}\text { Subjective Global } \\
\text { Assessment (Class B or } \\
\text { C) }\end{array}$ & $\begin{array}{l}\text { Combined infection- } \\
\text { related } \\
\text { complications (CDC } \\
\text { criteria) }\end{array}$ & $\begin{array}{l}\text { Infinity } \\
P=0.17 \text { (no } \\
\text { infection in } \\
\text { normally } \\
\text { nourished group) }\end{array}$ & $\vec{\imath}$ \\
\hline $\begin{array}{l}\text { Vivanco-Munoz } \\
\text { et al. }{ }^{23} \\
\text { Mexico }\end{array}$ & 2010 & $\begin{array}{l}\text { To determine the } \\
\text { incidence and risk } \\
\text { factors for nosocomial } \\
\text { infection in children } \\
\text { having open-heart } \\
\text { surgery }\end{array}$ & $\begin{array}{l}\text { Retrospective } \\
\text { cohort study }\end{array}$ & Low & $\begin{array}{l}289 \text { children requiring } \\
\text { cardiopulmonary bypass } \\
\text { surgery } \\
\text { Median age } 10.6 \text { months } \\
\text { (range } 3 \text { days }-36 \\
\text { months) }\end{array}$ & $\begin{array}{l}<90 \% \text { of weight/age } \\
\text { at birth; body mass } \\
\text { index } z \text {-score }<-2\end{array}$ & $\begin{array}{l}\text { Combined } \\
\text { pneumonia, } \\
\text { septicaemia, } \\
\text { mediastinitis; } \\
\text { pneumonia } \\
\text { (ventilation }>48 \mathrm{~h} \text { ) }\end{array}$ & $\begin{array}{l}\text { RR } 0.86 \\
(0.46-1.44) ; \\
\text { RR } 0.68 \\
(0.32-1.18)\end{array}$ & \\
\hline
\end{tabular}




\begin{tabular}{|c|c|c|}
\hline $\begin{array}{l}\text { Hatlen et al. } \\
\text { USA }\end{array}$ & 2010 & $\begin{array}{l}\text { To determine if poor } \\
\text { nutrition and/or positive } \\
\text { urinary cultures before } \\
\text { elective spinal surgery in } \\
\text { children with } \\
\text { meningomyelocele } \\
\text { increases the risk of } \\
\text { spinal infection }\end{array}$ \\
\hline . & & tifv \\
\hline
\end{tabular}

Farley et al. ${ }^{28} 2014$ To identify risk factors USA

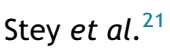
for the development of deep surgical site infection following spinal surgery

2014 To determine if children in extreme ranges of weight percentiles have higher rates of postoperative complications compared with children not in the extremes

2004 To determine rates and risk factors for surgical site infection following paediatric cardiac surgery

1990, To determine the 1993 incidence of wound infection and other hospital-acquired infections

\section{Retrospective Low} cohort study

Retrospective Low
case-control
study

59 children with mylomeningocele undergoing surgery for scoliosis

Median age 10 years 6 months (range 1.8-18 years)

70 children undergoing scoliosis surgery for spinal fusion, VEPTR lengthening/

replacement, growing rod lengthening replacement); 20 cases and 50 controls Average age not reported

Retrospective Moderate cohort study

\section{0,392 children}

undergoing surgical procedures grouped into low-, normal- or highweight percentiles Mean age per weight group: low, 6 years; normal, 7 years; high, 10 years

Prospective
nested
case- control
study

Low

38 children undergoing major paediatric cardiac surgery who developed surgical site infection, with 38 matched controls

Prospective cohort study

608 patients undergoing 676 general operative procedures (mainly gastrointestinal) requiring skin incision 137 neonates; 197 infants; 342 children
Serum albumin level Surgical site

RR 2.94

$<55 \mathrm{~g} / \mathrm{L}$ or infection (unclea

(1.38-6.26)

haematocrit $\leq 33 \quad$ criteria)

\section{Body mass index $<18.5 \mathrm{~kg} / \mathrm{m}^{2}$}

Delayed deep surgical site infection (CDC criteria)

Weight at or below

Surgical site

We fifth percentile of infection

national age and sex-

adjusted weight

(CDC criteria)

urinary tract

infection;

pneumonia

(NSQIPP/CDC

criteria)

Weight less than two standard deviations below norm for age

Surgical site infection (NNIS

criteria applied up to postoperative day 14)

Waterlow's weightfor-height $<80 \%$ expected (moderate malnutrition)

\section{Surgical site} infection (ASEPSIS score $>21$ );

pneumonia; septicaemia

(0.38-2.95); RR 10.14

(2.17-47.27);

RR 6.34
OR $2(0.58-6.86)$

OR 0.89

(0.77-1.02);

RR 1.84

(1.51-2.23);

RR 2.69

(2.13-3.41)

OR 2.1

(0.65-6.84)

(2.01-19.94) 

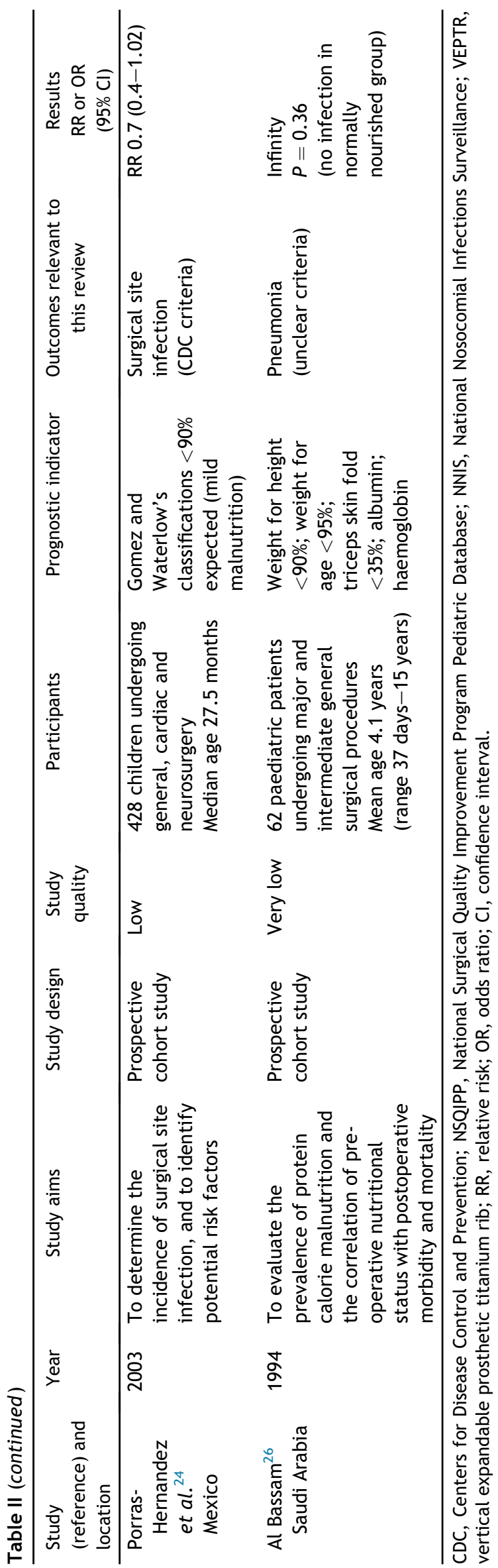

No studies were judged to provide high-quality evidence, and only two studies were judged to be of moderate quality. ${ }^{20,21}$ Downgrading the level of evidence for the remaining studies was mainly due to the study design (cohort studies had significant participant exclusions prior to study entry), inadequate definitions of exposure or outcome, or because of the lack of reported information with which to make a clear judgement regarding methodological quality.

Both moderate-quality studies demonstrated an initial association between undernutrition and postoperative infectious complications. However, following adjusted analysis, the direction of effect in the largest heterogeneous study did not support a relationship between SSI and undernutrition, ${ }^{21}$ whilst this relationship persisted in the smaller, homogeneous population. ${ }^{20}$ Lower-quality studies also demonstrated this initial association with significant confidence intervals, ${ }^{12,16}$ but were equally split in terms of direction of effect, with none able to demonstrate significance.

Anthropometric variables were used to assess nutritional status in all but one study, ${ }^{25}$ although varying thresholds for defining undernutrition were used. Due to significant heterogeneity, direct comparison across studies was complicated, and formal pooling of results for estimating effect was not appropriate. Weight-based assessments were the most common variable; this was not unexpected as this forms part of routine pre-operative assessment. Studies published prior to the year 2000 were more likely to use Waterlow's criteria to classify weight, whereas those published after 2000 were more likely to use $z$-scores, reflecting the recommendations of the World Health Organization. ${ }^{32}$ This wide variation in assessment method is likely to reflect the retrospective design of most studies, and the need to use weight-based data in addition to the technique most favoured during the study era.

A variety of definitions and classification systems were used for infection-related outcomes. The criteria of the Centers for Disease Control and Prevention were cited most commonly, ${ }^{4}$ but variable or unclear durations of follow-up made it difficult to determine if studies were treating participants comparably. Sample sizes were $<100$ in the majority of included studies. ${ }^{13,20,25-29}$ Studies were generally underpowered to detect important clinical differences, with only one study providing an a-priori power calculation, having an $80 \%$ chance of detecting an odds ratio of 2.1 , or a $50 \%$ chance at $1.5 .^{28}$ Studies that were specific to a surgical specialty were underpowered to detect differences, in view of the event rate of infection-related complications of $16 \%$ across all studies, with a range between $2 \%$ and $42 \% .{ }^{21,25}$ Studies that included multiple surgical specialties increased clinical heterogeneity significantly, especially when no attempt was made to control for surgical complexity. This heterogeneity increased the likelihood that any true effect of undernutrition on the incidence of infectious complications would not be uncovered.

Although attempts were made to identify unpublished literature, no studies were found. Using a search filter sensitive to the identification of studies regarding prognosis would not have excluded the identification of controlled trials of nutritional intervention in which control groups may have been eligible for inclusion, although none were identified. Despite an a-priori decision to exclude papers published in any language other than English, none were found that met the eligibility criteria of the review. 
The nature of the review question created complex search strings crossing many diagnostic fields, which may have contributed to the number of articles identified by backward and forward citation searching. Also, inconsistencies in subject heading terminology within the bibliographic databases searched, and variation between databases in how articles regarding prognosis are indexed, may have compounded this further.

The NOS was chosen as the preferred tool for quality assessment as both case-control and cohort studies were included. ${ }^{19}$ However, as the nature of the review question related to prognosis, the authors deviated from the protocol to enable the method of quality assessment to be adapted. The authors continued to assess quality using the NOS categories of selection, comparability and outcome or exposure (dependent on cohort or case-control methodology), but also incorporated the domains included in the framework developed by Hayden et al. specifically for studies considering prognosis. ${ }^{33}$ This adaptation was felt to enable more rigorous assessment of the quality of each included study in addressing the heterogeneity of both exposure and outcome measures. As observational studies are susceptible to uncontrolled confounding factors and bias, mainly in the selection of study participants, careful evaluation was undertaken to judge the reliability of the evidence provided. However, the reproducibility of this technique has not been tested.

The applicability of the findings is likely to be of relevance to the surgical specialties included in this review. As the higherquality studies did not include neonates, evidence is severely lacking with respect to children aged $<28$ days. In addition, future research needs to make a distinction between viewing undernutrition as a potential prognostic factor for infection, or exploring it as a potential risk factor for infection-related complications. In this way, studies will be adequately powered to detect clinical and statistical significance, with nutritional status being included in multi-variate analysis of potential confounders on outcome.

The review question remains unanswered. However, it remains an important question, particularly to those patient populations with chronic disease where growth failure has already been recognized and who will require surgical intervention as part of their management. ${ }^{8,34}$ Especially pertinent are those surgical specialties where patients will be critically ill postoperatively, and it is anticipated that they will require a proportion of their recovery time within an intensive care environment. These patient populations are known to be most vulnerable to postoperative morbidity, and are most vulnerable to further nutritional depletion during their inpatient stay. ${ }^{6,9,10}$

There is a need for large, adequately powered prospective studies incorporating a gold-standard method for nutritional assessment, with robust and consistently applied definitions of undernutrition and infectious complications. If undernutrition is a risk factor for infection, aspects of pre- and postoperative feeding practices could be modified in order to reduce the physical, psychosocial and financial burdens associated with HCAls in children.

\section{Acknowledgements}

The authors wish to thank Heitor Pons Leite for responding to RH's queries.

\section{Conflict of interest statement}

None declared.

\section{Funding sources}

$\mathrm{RH}$ is receiving PhD sponsorship from the University of Central Lancashire, and this work will contribute to her final thesis. No other funding was received to support this work.

\section{References}

1. Adams-Howell $P$, Bhabra $M$, Enright $M$, Kiernan $M$, Kolvekar $S$, Trueman P. Under the knife - taking a zero tolerance approach to preventable surgical site infections in UK hospitals 2011. Available from URL: http://www.carefusion.co.uk/documents/inter national/continuing-education/infection-prevention/IP_Underthe-knife_CE_EN.pdf.

2. Mauger B, Marbella A, Pines E, Chopra R, Black ER, Aronson N. Implementing quality improvement strategies to reduce healthcare-associated infections: a systematic review. Am J Infect Control 2014;42:S274-S283.

3. National Collaborating Centre for Women's and Children's Health. Surgical site infection: prevention and treatment of SSI. London: RCOG Press; 2008.

4. Mangram AJ, Horan TC, Pearson ML, Silver LS, Jarvis WR. Guideline for prevention of surgical site infection. Infect Control Hosp Epidemiol 1999;20:247-278.

5. Mehta NM, Corkins MR, Lyman B, et al. Defining pediatric malnutrition: a paradigm shift toward etiology-related definitions. JPEN J Parenter Enteral Nutr 2013;37:460-481.

6. Pichler J, Hill SM, Shaw V, Lucas A. Prevalence of undernutrition during hospitalization in a children's hospital: what happens during admission? Eur J Clin Nutr 2014;68:730-735.

7. Aurangzeb B, Whitten KE, Harrison B, et al. Prevalence of malnutrition and risk of under-nutrition in hospitalized children. Clin Nutr 2012;32:35-40.

8. Pawellek I, Dokoupil K, Koletzko B. Prevalence of malnutrition in paediatric hospital patients. Clin Nutr 2008;27:72-76.

9. Delgado AF, Okay TS, Leone C, Nichols B, Del Negro GM, Vaz FAC. Hospital malnutrition and inflammatory response in critically ill children and adolescents admitted to a tertiary intensive care unit. Clinics 2008;63:357-362.

10. Mitting R, Marino L, Macrae D, Shastri N, Meyer R, Pathan N. Nutritional status and clinical outcome in post term neonates undergoing surgery for congenital heart disease. Pediatr Crit Care Med 2015; 16:448-452.

11. Wessner S, Burjonrappa S. Review of nutritional assessment and clinical outcomes in pediatric surgical patients: does preoperative nutritional assessment impact clinical outcomes? J Pediatr Surg 2014;49:823-830.

12. Secker DJ, Jeejeebhoy KN. Subjective global nutritional assessment for children. Am J Clin Nutr 2007;85:1083-1089.

13. Leite HP, Fisberg M, Novo NF, Nogueira EB, Ueda IB. Nutritional assessment and surgical risk markers in children submitted to cardiac surgery. Sao Paulo Med J 1995;113:706-714.

14. Wilczynski NL, Haynes RB. Developing optimal search strategies for detecting clinically sound prognostic studies in MEDLINE: an analytic survey. BMC Med 2004;2:23-27.

15. Wilczynski NL, Haynes RB. Optimal search strategies for identifying clinically sound prognostic studies in EMBASE: an analytic survey. J Am Med Inform Assoc 2005;12:481-485.

16. Bhattacharyya N, Kosloske AM. Postoperative wound infection in pediatric surgical patients: a study of 676 infants and children. J Pediatr Surg 1990;25:125-129.

17. Bhattacharyya N, Kosloske AM, MacArthur C. Nosocomial infection in pediatric surgical patients: a study of 608 infants and children. J Pediatr Surg 1993;28:338-343. 
18. Higgins JPT, Green S, editors. Cochrane handbook for systematic reviews of interventions. Version 5.1.0 (updated March 2011). London: The Cochrane Collaboration; 2011.

19. Wells GA, Shea B, O'Connell D, et al. The Newcastle-Ottawa Scale (NOS) for assessing the quality of non-randomized studies in metaanalyses. 2011. Available at: http://www.ohri.ca/programs/ clinical_epidemiology/oxford.asp [last accessed November 2013].

20. Anderson JB, Kalkwarf HF, Kehl JE, Eghtesady P, Marinio BS. Low weight-for-age $z$-score and infection risk after the Fontan procedure. Ann Thorac Surg 2011;91:1460-1466.

21. Stey AM, Moss RL, Kraemer K, Cohen ME, Ko CY, Hall BL. The importance of extreme weight percentile in postoperative morbidity in children. J Am Coll Surg 2014;218:988-996.

22. National Obesity Observatory. A simple guide to classifying body mass index in children. Wootton-by-Woodstock: SPH Solutions for Public Health; 2011.

23. Vivanco-Munoz N, Talavera JO, Juanico-Enriquez A, Clark P. Risk factors for nosocomial infections in children who had open-heart surgery. J Pediatr Infect Dis 2010;5:339-345.

24. Porras-Hernandez JD, Vilar-Compte D, Cashat-Cruz M, OrdericaFlores RM, Bracho-Clanchet E, Avila-Figueroa C. A prospective study of surgical site infections in a pediatric hospital in Mexico City. Am J Infect Control 2003;31:302-308.

25. Hatlen T, Song K, Shurtleff D, Duguay S. Contributory factors to postoperative spinal fusion complications for children with myelomeningocele. Spine 2010;35:1294-1299.
26. Al-Bassam AA. Clinical significance of preoperative nutritional status in pediatric surgical patients. Ann Saudi Med 1994;14:511-513.

27. Rojratsirikul C, Sangkhatthat S, Patrapinyokul S. Application of subjective global assessment as a screening tool for malnutrition in pediatric surgical patients. J Med Assoc Thai 2004;87:939-946.

28. Farley FA, Ying L, Gilsdorf JR, et al. Postoperative spine and VEPTR infections in Children: a case-control study. J Pediatr Orthop 2014;34:14-21.

29. Nateghian A, Taylor G, Robinson JL. Risk factors for surgical site infections following open-heart surgery in a Canadian pediatric population. Am J Infect Control 2004;32:397-401.

30. Wilson AP, Treasure T, Sturridge MF, Gruneberg RN. A scoring method (ASEPSIS) for postoperative wound infections for use in clinical trials of antibiotic prophylaxis. Lancet 1986;327:311-312.

31. National Nosocomial Infection Surveillance System. National Nosocomial Infection Surveillance System report, data summary from January 1992 to June 2002. Am J Infect Control 2002; 30:458-475.

32. World Health Organization. Child growth standards. Geneva: WHO; 2006.

33. Hayden JA, Cote P, Bombardier C. Evaluation of the quality of prognosis studies in systematic reviews. Ann Intern Med 2006; 144:427-438.

34. Joosten KFM, Hulst JM. Prevalence of malnutrition in pediatric hospital patients. Curr Opin Pediatr 2008;20:590-596. 